Int. J. Dev. Biol. 56: 535-542 (2012)

doi: $10.1387 / \mathrm{ijdb} .113462 \mathrm{rs}$

\title{
The Hydra genome: insights, puzzles and opportunities for Developmental Biologists
}

\author{
ROBERT E. STEELE* \\ Department of Biological Chemistry and the Developmental Biology Center, University of California, Irvine, CA, USA
}

\begin{abstract}
The sequencing of a Hydra genome marked the beginning of a new era in the use of Hydra as a developmental model.Analysis of the genome sequence has led to a number of interesting findings, has required revisiting of previous work, and most importantly presents new opportunities for understanding the developmental biology of Hydra. This review will describe the history of the Hydra genome project, a selection of results from it that are relevant to developmental biologists, and some future research opportunities provided by Hydra genomics.
\end{abstract}

KEY WORDS: Hydra, genome, evolution, Cnidaria

\section{Introduction}

It has become creed that understanding the biology of an organism in depth requires the sequence of its genome. The genome sequence provides a parts list, informs regarding the evolutionary history of the organism, and is essential for carrying out functional studies that involve manipulating genes. While Hydra has been used as an experimental organism for nearly 270 years (Trembley, 1744), our ability to investigate its biology has increased dramatically since the sequence of its genome became available (Chapman et al., 2010). Hydra is a cnidarian in the family Hydrozoa (Fig. 1). Unlike most hydrozoans, Hydra lives in freshwater and lacks the larval and medusa stages typical of hydrozoan life cycles. Two recent phylogenetic analyses (Kawaida et al., 2010; Martínez et al., 2010) have shown that the genus Hydra consists of four clades (Fig. 2), that have diverged from a common ancestor over the last 50-60 million years.

Hydra's appeal as a model for studying developmental processes lies in the simplicity of its composition and structure (Campbell and Bode, 1983), its remarkable powers of regeneration (Holstein et al., 2003; Bosch, 2007), and its accessibility to a variety of experimental manipulations (Lenhoff, 1983). The adult Hydra polyp consists of two concentrically arranged epithelial layers surrounding a gastric cavity (Campbell and Bode, 1983). The animal has a single axis; at the oral end is the mouth opening, surrounded by a ring of tentacles and at the aboral end is an adhesive disk called the foot or basal disk. In addition to the two epithelial cell layers, which constitute distinct developmental lineages in the adult polyp, Hydra has a third cell lineage, the interstitial cell (i-cell) lineage. This lineage contains multipotent stem cells that give rise to nerve cells, nematocytes, gland cells, and gametes (David and Murphy, 1977; Campbell and Bode, 1983; Bode, 1996).

Hydra has served as a research model for pattern formation, cell differentiation, and stem cell biology. Studies of pattern formation in Hydra have focused on how the single axis of the adult polyp is maintained during growth, asexual budding, and regeneration (Bode, 2011; Bode, 2012; Shimizu, 2012). Research on cell differentiation in Hydra has primarily been concerned with how the various differentiation products of the i-cell lineage - nerves, nematocytes, gametes and gland cells - are generated and maintained (Bode, 1996; David, 2012; Nishimaya-Fujisawa, 2012). The multipotent stem cells that give rise to the differentiated cells of the i-cell lineage (David and Murphy, 1977; Bosch and David, 1987) have been the focus of studies to understand how stem cells function and their evolutionary history in metazoans (Bosch, 2009).

\section{Hydra developmental biology before genomics}

While studies at the cell and tissue levels had led to many important insights into developmental processes in Hydra, it became clear in the mid-1980s that the application of molecular methods, particularly cloning of genes, would be essential for further progress. Reports of the cloning of the first protein-coding genes from Hydra, a cytoplasmic actin gene (Fisher and Bode, 1989) and a src family protein-tyrosine kinase gene (Bosch et al., 1989), were published in 1989. Subsequently other genes, particularly Hydra homologues of genes with known developmental roles in other metazoans (e.g. homeobox genes), were cloned from Hydra by screening of cDNA libraries with oligonucleotides, heterologous cloned genes, or differential cDNA probes, and by PCR (Kurz et al., 1991; Chan et al., 1992; Holstein et al., 1992; Schlaepfer et al., 1992; Schummer et

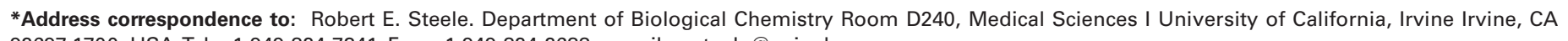
92697-1700, USA. Tel: +1-949-824-7341. Fax: +1-949-824-2688. e-mail: resteele@uci.edu 
al., 1992; Naito et al., 1993; Shenk et al., 1993). Having cloned genes in hand made it possible to begin investigating the roles of genes in developmental processes in Hydra. With the development of a robust whole-mount in situ hybridization method for use with Hydra (Grens et al., 1995; Grens et al., 1996), it was possible to examine gene expression patterns in spatial and temporal detail in normal and experimentally manipulated animals. These manipulations included regeneration, changing of cell composition (Bode, 1983), and chemical treatments to perturb development (Müller, 1989; Hassel and Berking, 1990; Broun et al., 2005).

Expression patterns in and of themselves often provided insight into likely developmental roles for genes in Hydra. Particularlygood examples include the HyAlx gene and the Wnt3 gene. The HyAlx gene is expressed in a ring of ectodermal epithelial cells at the base of the tentacles (Smith et al., 2000). This expression pattern immediately suggested a role for the HyAlx gene in the formation of tentacles, a role that was confirmed experimentally (Smith et al., 2000). The Wnt3 gene is expressed in a small number of epithelial cells at the tip of the hypostome (Hobmayer et al., 2000). Because it was known that the tip of the hypostome had organizer activity (Browne, 1909), the expression pattern of Wnt3 suggested that Wnt signaling was a component of the axial organizer. Subsequent studies (Broun et al., 2005) demonstrated that the canonical Wnt signaling pathway is a key component of the Hydra head organizer.

While expression studies of cloned genes accelerated progress in our understanding of the genes involved in developmental processes in Hydra, methods for specifically altering the expression of a given gene were clearly needed. With the discovery of RNA interference (RNAi), it was obvious that this method could be an important tool for carrying out functional studies of genes in Hydra. The first attempt to perturb gene expression in Hydraby RNAi involved electroporation of dsRNA corresponding to the ks1 gene, a gene expressed in the tentacles and the hypostome (Lohmann et al., 1999). As expected for a gene putatively involved in head formation, polyps exposed

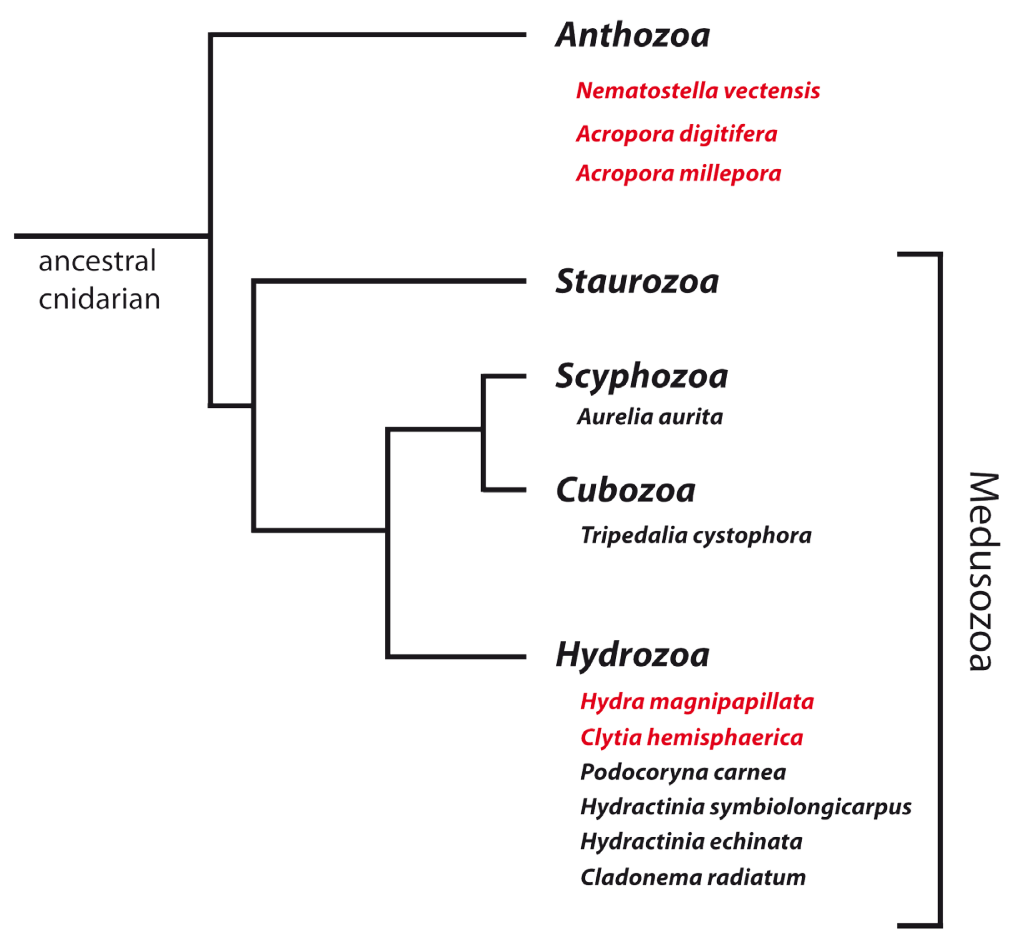

to the ks1 dsRNA showed marked delays in head regeneration. RNAi carried out by electroporation has been used to study the functions of additional Hydra genes (Lohmann and Bosch, 2000; Smith et al., 2000; Cardenas and Salgado, 2003; Takahashi et al., 2005; Amimoto et al., 2006; Khalturin et al., 2008), and a method has now been developed for carrying out RNAi in Hydra by feeding the animals bacteria producing dsRNA for the target gene (Chera et al., 2006; Miljkovic-Licina et al., 2007; Chera et al., 2009; Chera et al., 2011). Despite these efforts, RNAi is not yet a robust, widely used technology for functional studies in Hydra. It is hoped that continued efforts will lead to gene knockdown methods that can be easily and reproducibly applied to any Hydra gene of interest.

By the end of the 1990s it became clear that the "one gene at a time" approach to identifying and studying genes involved in development in Hydra was limiting the rate at which knowledge could be acquired. A genomics solution was clearly needed.

\section{Genomics come to Hydra developmental biology}

Genomics research with Hydra began in 2001 with two EST projects, one funded by the United States National Science Foundation and carried out as a collaborative effort between UC Irvine and the Genome Sequencing Center at Washington University and the other carried out at the National Institute of Genetics in Mishima, Japan. Together these projects generated $\sim 170,000$ ESTs from Hydra. The U.S. project also sequenced ESTs from two other hydrozoans: $\sim 3500$ ESTs from Podocoryna carnea and 9000 ESTs from Hydractinia echinata (Soza-Ried et al., 2010).

Sequencing of a Hydra genome was recommended by the Comparative Genome Evolution Working Group at the National Human Genome Research Institute (NHGRI) in 2004. Approval for sequencing of 18 organisms, including Hydra magnipapillata, was announced in an NHGRI press release on August 4, 2004. Strain 105 of Hydra magnipapillata was chosen to be sequenced because of its widespread use for Hydra research and the fact that it was used for construction of most of the cDNA libraries for the two Hydra EST projects. In addition the 105 strain of Hydra magnipapillata was used for the Hydra Peptide Project (Takahashi et al., 1997; Fujisawa, 2008) and a number of mutant strains of $H$. magnipapillata had been isolated by Tsutomu Sugiyama's group in Mishima (Sugiyama and Fujisawa, 1977; Sugiyama, 1983; Shimizu, 2012). The 105 strain of $H$. magnipapillata was recloned from a single polyp in Hans Bode's lab at UC Irvine to provide a source of DNA. The genome was sequenced by the Sanger whole genome shotgun method at the J. Craig Venter Institute; sequencing coverage was $\sim 6 x$. Fixed voucher specimens of the 105 strain from UC Irvine were deposited in the invertebrate collections at Yale's Peabody Museum. In

Fig. 1. Cnidarian phylogenetic tree. The branching order for the five cnidarian classes is shown (Marques and Collins, 2004; Collins et al., 2006). Species that are model systems for studies at the molecular and genomics level in each class are shown and those whose genomes have been sequenced are in red. Podocoryna carnea is commonly, but incorrectly, referred to as Podocoryne carnea (Calder, 1988). Citations for the genome projects are as follows: Hydra magnipapillata (Chapmanetal., 2010); Nematostella vectensis (Putnam et al., 2007); Clytia hemisphaerica (Houliston et al., 2010); Acropora digitifera (Shinzato et al., 2011); Acropora millepora (www.coralbase.org). 


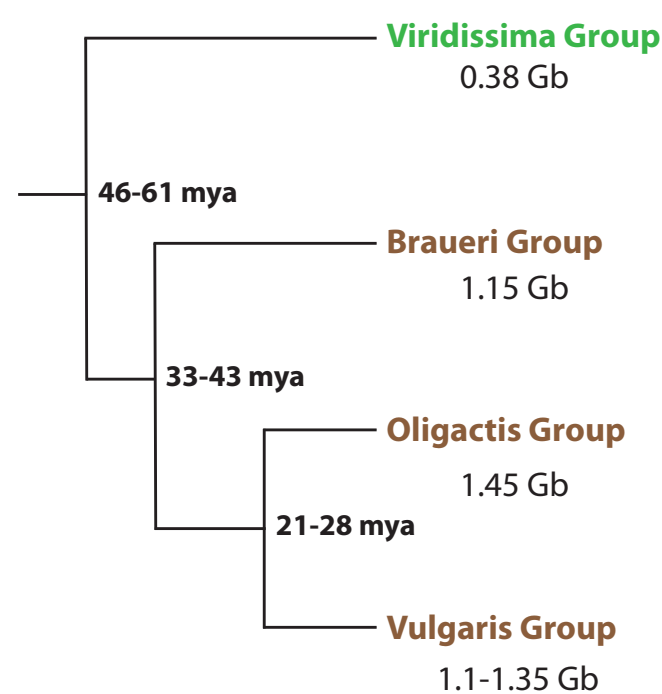

Fig. 2. Phylogenetic tree of the genus Hydra. The tree is adapted from Martínez et al., (Martínez et al., 2010). Estimated times in millions of years ago (mya) for the divergences of the various clades are indicated. The Viridissima group consists of the green Hydra species $\mathrm{H}$. viridissima, which contains algal endosymbionts. The Braueri, Oligactis, and Vulgaris groups contain brown Hydra species, so-called because they lack algal endosymbionts. Under the group names are the genome sizes (in gigabase pairs) measured for species within the group (Zacharias et al., 2004; Hemmrich et al., 2007). Only single species have been measured from the Viridissima, Braueri, and Oligactis groups. Three species have been measured from the Vulgaris group.

addition, the Venter Institute deposited the remaining genomic DNA from the project in the Peabody Museum's Cryo Collection (http:// peabody.yale.edu/collections/cryo-facility/cryo- facility).

Following the completion of sequencing, two assemblies of the genome were done. A detailed description of the two assemblies is given in the Supplementary Material included with the paper describing the genome sequence (Chapman et al., 2010). Both assemblies are of relatively low quality, i.e. the contigs are short, compared to the assemblies of other animal genomes. This is largely because it was not possible to obtain large insert libraries (e.g. BAC libraries) due to the instability of the A+T-rich Hydra DNA in E. coli (Pieter de Jong et al., unpublished observations). Fosmid cloning was attempted at the Venter Institute but only about one third of the resulting clones yielded usable sequence. Efforts are under way to use a combination of happy mapping and Illumina sequencing to improve the assembly (Jiang et al., 2009). Long read sequencing methods, e.g. strobe sequencing with the PacBio RS system (Ritz et al., 2010), provide another possible approach for improving the assembly of the Hydra genome.

\section{What have we learned from the genome sequence?}

The results from a number of analyses of the Hydra genome sequence have been reported by Chapman et al., (2010) and recently reviewed by Steele et al., (2011). The focus here will be on those aspects of the genome that are particularly relevant to developmental biology.

\section{What genes are present?}

One of the first questions that the genome sequence provides an answer to is "are there Hydra orthologues of genes known to play key developmental roles in the well-studied bilaterian developmental models? The answer to this question is a definite yes. Hydra has all of the major classes of signaling molecules and transcription factors that are well known from studies in bilaterians. And in some cases, the number of genes in the family is similar to that in bilaterians. For example, the Wnt gene family in Hydra is comparable in size to that of bilaterians (Lengfeld et al., 2009), indicating that much of the diversification of this developmentally important family preceded the divergence of cnidarians from other metazoans.

Having a sequenced genome has substantially accelerated progress in delineating the components of developmental pathways in Hydra. Rather than having to identify genes encoding the various components in a developmental pathway or developmental process one at a time, all of the genes can be identified quickly in silico. Examples of this are presented in the Hydra genome paper (Chapman et al., 2010) in which genes potentially involved in head organizer function and in cell-cell and cell-substrate interactions were cataloged.

While the Hydragenome was being sequenced, a suite of genes (Myc, Nanog, Klf4, Oct4, and Sox2) that confers pluripotency on differentiated mammalian cells was identified by Yamanaka's group (Takahashi and Yamanaka, 2006). Given Hydra's history as a model for the study of stem cells (Bode, 1996; Bosch, 2009), it was of considerable interest to search the genome for homologues of the mammalian pluripotency-inducing genes. This search has not yet reached a clear conclusion. We can say with certainty that Myc genes are present in Hydra (Hartl et al., 2010). At least one of the Hydra Myc genes is expressed strongly in the stem cells of the interstitial lineage (Hartl et al., 2010; Hobmayer et al., 2012).

It appears that Nanog and Klf4 genes are absent from the Hydra genome (Chapman et al., 2010). The situation with Oct4, a member of class 5 of the POU family, is currently unclear. An Oct4 homologue appears to be absent from Hydra. However, Polynem, a POU family gene in Hydractinia, has been shown to have a role in stem cell development (Millane et al., 2011; Plickert et al., 2012). Phylogenetic analysis does not resolve the relationship of Polynem to other members of the POU family (Millane et al., 2011). Additional studies of the POU family in cnidarians are clearly warranted to clarify the evolutionary history of members of this family and their role in stem cell biology. Functional studies, for example determining whether putative cnidarian homologues of Oct4 can functionally substitute for Oct4 in a mammalian setting, are particularly important in addressing this issue since sequence comparisons alone cannot determine whether genes have shared functions.

At the time the genome paper was published, the evolutionary relationship between the two Hydra genes in the SoxB group (the SoxBgroup includes Sox2) and Sox2genes in vertebrates was not clear. Since then, a detailed study of the phylogeny and expression patterns of the Sox genes in the hydrozoan Clytia hemisphaerica has appeared (Jager et al., 2011). This study showed that members of the SoxB group in Clytia do not have an orthologous relationship to the SoxB group members in vertebrates. Nonetheless, some of the SoxB group genes in Clytia are expressed in stem cells (Jager et al., 2011). An interpretation of these results is that the ancestral SoxB group gene had an ancient, conserved role in stem cell function that pre-dates the allocation of this role to individual 
SoxB group paralogues in hydrozoans and vertebrates. As with Oct4, functional studies will be required to test this hypothesis.

\section{What genes are absent?}

Perhaps as interesting as finding out what genes involved in development are present in the Hydra genome is finding out what genes are absent. Comparisons of the hox/parahox superfamily of homeobox genes in Hydra with other hydrozoans and the anthozoan Nematostella have shown that this superfamily has suffered a number of losses in Hydra (Chourrout et al., 2006; Quiquand et al., 2009; Chapman et al., 2010; Steele et al., 2011). These losses have generated in Hydra what is essentially a "natural knockout" line for the missing genes, demonstrating that it is possible to build a metazoan without these particular genes. Most interesting of these losses is the absence of Emx and Evx orthologues. Orthologues of these two genes have been identified in other cnidarians including the hydrozoans Sarsia sp. (Bridge and Steele, unpublished; GenBank accession number AF326771), Hydractinia symbiolongicarpus (Mokady et al., 1998), Clytia hemisphaerica (Chiori et al., 2009), Podocoryne carnea (D. Bridge and D. Martínez, unpublished), and Cladonema pacificum (R. Greenspan et al., unpublished). Comparisons of the life cycles of Hydra and these other hydrozoans leads to the conclusion that absence of the Emx and Evx genes in Hydra correlates with the absence of the planula larva stage (Chapman et al., 2010). This is an interesting finding that suggests the possibility that loss of these genes was causative in the loss of the planula stage of the Hydralife cycle or that these two genes became dispensable when the planula stage was lost. It would obviously be of interest to know whether either of these genes is missing in other members of the clade Aplanulata (i.e. hydrozoans that lack a planula larva) (Collins et al., 2006).

Surprisingly absent from the Hydra genome assembly are genes encoding two previously characterized proteins that have been reported to play roles in regeneration and patterning. An 11-amino acid peptide termed head activator $(\mathrm{HA})$ was isolated from Hydra in the late 1970s based on its ability to accelerate head regeneration (Schaller, 1973; Schaller and Bodenmüller, 1981). HA was studied intensively, but a sequence that could encode it has not been identified in the Hydra genome. In addition to being reported from cnidarians, HA was also reported to be present in mammals (Schaller, 1975). This suggests that it should be present in the genomes of many metazoans. Thus we are left with a mystery. Given that it contains only 11 amino acids, HA could be synthesized by a route that does not involve translation. If $\mathrm{HA}$ is encoded by a gene and its predicted 33 nucleotide coding sequence is interrupted by one or more introns, it would be difficult to identify the gene. It is also possible that the HA gene is contained in a portion of the Hydra genome that is not included in the assembled version.

Another puzzling case of a missing gene is that of the peptide HEADY (Lohmann and Bosch, 2000). A fragment of HEADY cDNA was identified by a differential display PCR screen for genes whose expression changes during regeneration. The putative full-length 369 nucleotide HEADY cDNA is predicted to encode a 23-amino acid precursor protein, which is predicted to yield the mature 12 amino acid HEADY peptide following proteolytic processing. The HEADY cDNA sequence is not found in the Hydra genome as- sembly. As with the case of HA, the absence of the HEADY gene from the Hydragenome assembly could be due to incompleteness of the assembly. Since the original publication on HEADY in 2000, no additional information on this gene has appeared.

That gap junctions are present in Hydra was convincingly demonstrated by electron microscopic studies (Wood and Kuda, 1980) and by dye coupling experiments (Fraser and Bode, 1981). That they have developmental roles in Hydra was first suggested by the study of Fraser et al., (1987) in which a polyclonal antiserum against a vertebrate connexin was shown to decrease the efficacy of the head inhibition gradient when the antibodies were introduced into Hydra. These results were interpreted as indicating that the inhibitor either moved through gap junctions are acted through a pathway involving gap junctions. Given these results, it came as a surprise when no connexins gene could be found in the Hydra genome. There were however, genes encoding innexins (Alexopoulos et al., 2004), the proteins that were known to form gap junctions in other invertebrates. Given the absence of any sequence conservation between innexins and connexins, it seems unlikely that the results of Fraser et al., can be explained by cross-reaction between the vertebrate connexin antibody and Hydra innexins. Nonetheless, the hypothesis that gap junctions have a role in patterning as originally tested by the studies of Fraser et al., (1987) is still valid and clearly worth revisiting, with innexins being the test subject this time around.

\section{What genes are novel?}

While genes that are conserved among animals are of obvious importance for understanding Hydra development, there was reason to expect that Hydra had evolved novel genes that play important roles in development. This possibility was the motivation for the Hydra peptide project (Takahashi et al., 1997; Fujisawa, 2008), which had the goal of identifying novel peptides involved in developmental processes in Hydra (Fujisawa and Hayakawa, 2012). This project has led to the identification of the Hym-301 peptide, which is involved in head formation, Hym-355 and the PW peptides, which play stimulatory and inhibitory roles, respectively in nerve cell differentiation, and Hym-346 and Hym-323 peptides, which have roles in foot formation (Grens et al., 1999; Takahashi etal., 2000; Takahashi et al., 2005; Takahashi and Fujisawa, 2009; Takahashi et al., 2009). Although Hayakawa et al., (2007) have shown that a computational approach can be used to identify potential precursors to peptides in Hydra in ESTs or in gene models from the Hydra genome, functional screens of the sort developed by the Hydra Peptide Project clearly still have a role to play in defining the molecules that control developmental processes in Hydra, with the genome sequence playing an enabling role.

Further studies of Hym-301 (Khalturin et al., 2008) led Khalturin et al., (2009) to develop the concept of taxonomically restricted genes (TRGs). TRGs are genes that are found in a restricted set of taxa and which control taxon-specific features. The Hym-301 gene fits the criterion for a TRG since it is found in Hydra but in no other animals, including the anthozoan Nematostella. When a transgenic line was created that overexpressed Hym-301, alterations in tentacle development and number were seen (Khalturin et al., 2008), suggesting that relatively subtle changes in the regulation of TRGs such as Hym-301 can alter morphological features of the animal. Extending these studies to other TRGs will provide 
insight into how many of the features of Hydra's development and morphology are based on TRGs.

\section{From colonial to solitary - using genomics to understand the evolution of the Hydra foot}

The evolution of the genetic circuits underlying novel structures in animals is of long-standing interest to developmental biologists. Cnidarians provide particularly fertile material in this regard because of their remarkable diversity of form. It is believed that the adult form of the ancestor of Aplanulata was a solitary polyp (Paulyn Cartwright, personal communication). The clade Aplanulata belongs to the subclass Hydroidolina, and most of the clades in Hydroidolina are colonial. Thus those Aplanulata species with a solitary polyp (such as Hydra) likely evolved from colonial forms. This scenario raises the interesting question of how the Hydra foot evolved - did it primarily involve well-known developmental regulatory genes or did TRGs play a significant role? From studies of expression patterns of various genes and results from the Hydra Peptide Project, it appears that foot formation involves both conserved genes (Grens et al., 1996; Steele et al., 1996) and TRGs (Grens et al., 1999; Bridge et al., 2000). In at least one case for the foot we even have regulatory linkage between a conserved gene (and NK homeobox gene) and a TRG (Hym-346) (Thomsen et al., 2004).

Genome sequences will be key to understanding the evolutionary origins of the Hydra foot. By comparisons between the genome of Hydra and the genomes of closely related species that are colonial or solitary one can determine whether genes known to play roles in foot formation in Hydra are present in colonial forms too, present only in solitary forms, or present only in Hydra. Clytia hemisphaerica, like Hydra, is a member of Hydroidolina but it is colonial. The Clytia genome is being assembled and should be available soon (Houliston et al., 2010). RNA-seq datasets from normal and regenerating feet in Hydra, coupled with in situ hybridization will increase the number of genes for comparative purposes.

\section{Transgenics - manipulating the genes the genome sequence provides}

Following the publication of RNAi methods for Hydrabut before the completion of the genome sequence, a landmark in Hydra research was established by the publication in 2006 of a method for making stably transgenic Hydra (Steele, 2006; Wittlieb et al., 2006). With this method, a new set of options became available for functional tests of the genes that the genome sequence provided for study. Making a transgenic Hydra involves injection of plasmid DNA into a blastomere of a 1-8 cell embryo. Use of this method in a number of labs over the past five years has revealed that it is remarkably robust, technically simple, and easy to implement in any lab that has experience culturing Hydra, which is itself quite easy. It is amusing that GFP is now being used as a research tool in a hydrozoan, given that it was originally isolated from a hydrozoan (Aequorea victoria). Fortunately, Hydra has no endogenous fluorescence, the fluorescent protein genes that it might be expected to contain given that it is a hydrozoan, have apparently been secondarily lost, as no GFP-related genes are present in the Hydragenome (Chapman et al., 2010). This absence of endogenous fluorescence makes it particularly straightforward to image any aspect of a transgenic animal.
Transgenic methods for Hydra not only allow one to manipulate genes, but they also make it possible to investigate the cis-acting elements that regulate gene expression during development in Hydra. The results of the first such promoter "bashing" study in Hydra, an analysis of the promoter of the Wnt3 gene, was recently published. By classical promoter deletion studies and use of GFP as a reporter, Nakamura et al., (2011) were able to define both positive and negative cis-elements in the Wnt3 promoter. Despite the large size of the Hydragenome (1 Gb), the promoters that have been characterized so far by construction of transgenic lines are surprisingly small (on the order of 1-2 kb). This finding bodes well for further efforts to define the logic of gene regulation in Hydra.

\section{Opportunities provided by the Hydragenome sequence}

The availability of a genome sequence has already provided us with much insight into developmental processes in Hydra. But even more importantly, the sequence points toward exciting opportunities for learning more. Some of these possibilities are discussed below.

\section{The Hydra transcriptome - still much to learn}

There are currently 170,000 Hydra ESTs in GenBank, generated by Sanger sequencing. By today's standards this is a tiny number. The Hydra transcriptome clearly needs revisiting using next generation sequencing technologies (i.e. RNA-seq). Data from RNA-seq would improve gene annotation for the existing genome sequence, and more importantly, show the extent of alternative splicing in Hydra. We currently know very little about alternative splicing in Hydra, but what we do know (Hwang et al., 2010) suggests that it would be of interest to know more.

\section{Epigenetics - How is the Hydra genome marked?}

The past few years have seen an explosion of interest and effort in the area of epigenetics. A polycomb gene from Hydra has been cloned and characterized (Khalturin et al., 2007), but otherwise Hydra has missed out in this area. With a sequenced genome, a clearly defined stem cell system, and very plastic patterning, Hydra is ripe for studies to determine how its genome operates at the epigenetic level. Mapping of the Hydra methylome and the application of ChIP-seq to Hydra using antibodies that detect histone modifications are advances that are eagerly awaited.

\section{Do non-coding RNAs regulate developmental processes in Hydra?}

Non-coding RNAs play important roles in regulating developmental processes in bilaterian animals (Pauli et al., 2011). What role they play in Hydra development is completely unexplored territory. A small number of microRNAs were identified as part of the Hydra genome project (Chapman et al., 2010), but this is clearly a very incomplete accounting. And no attempt has been made to identify genes for long non-coding RNAs in the Hydra genome. This is clearly an area where attention is needed.

\section{Using zinc-finger and TALE nucleases to manipulate the Hydra genome}

With a genome sequence available, we now have $\sim 20,000$ Hydra genes that are targets for disruption to understand their function. RNAi is not yet up to the task, and gene disruption by 
AEP male mutagenized with EMS<smiles>C=C1CCCCC1</smiles>

\section{$x$}

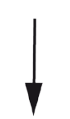
wild type AEP females

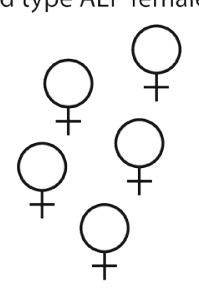

$F 1$ lines

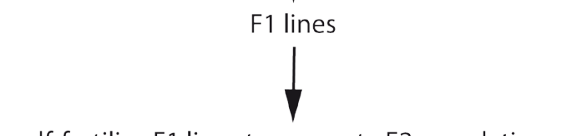

self-fertilize F1 lines to generate F2 populations

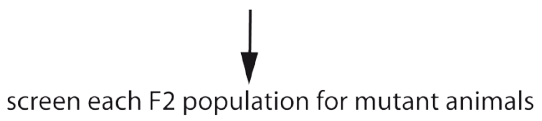

A

$\downarrow$

pool animals from each $\mathrm{F} 2$ population based on phenotype (wt or mutant)

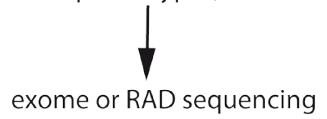

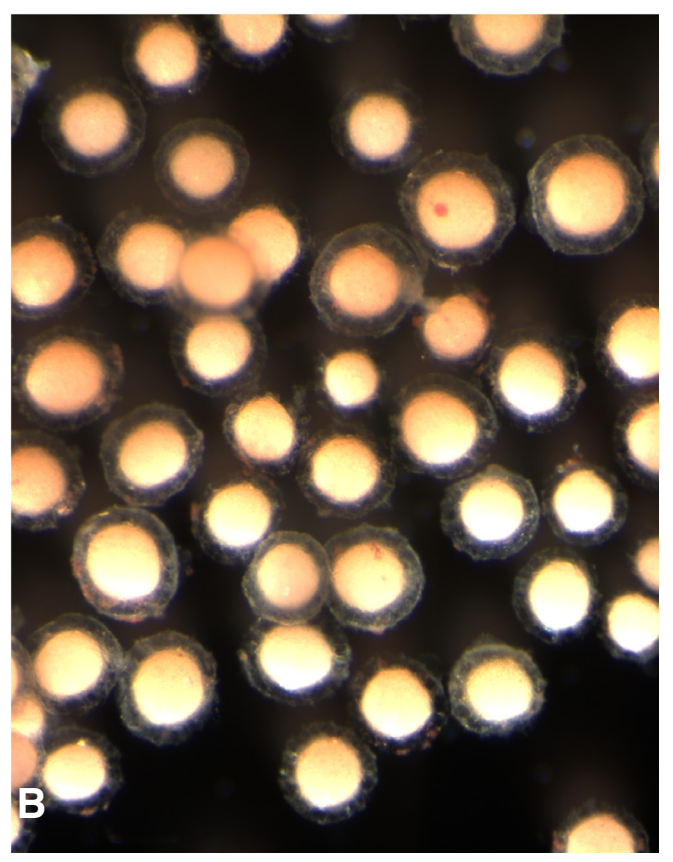

C. Dana, unpublished). Fig. 3 shows a possible scheme for carrying out a mutagenesis screen with Hydra.

\section{Conclusion}

The completion of the first Hydra genome sequence was a propitious moment for Hydra developmental biologists. Labs already working on Hydra were quick to take advantage of the sequence for studies of developmental processes. And in an example of "build it and they will come" the availability of a Hydra genome sequence has convinced new researchers to use Hydra as a developmental model. Sequencing costs continue to drop, bioinformatics methods are becoming more powerful, and tools for manipulating genomes continue to evolve; it's a great time to be a Hydra developmental biologist.

\section{Acknowledgements}

Research in the author's laboratory is

Fig. 3. A genetic screen using Hydra. (A) An approach for screening for mutants in Hydra. (B) A population of cuticle stage Hydra embryos. The mutant screening approach is described in detail in the text.

site-specific recombination appears impossible. Recently two new methods have become available for creating loss of gene function - zinc-finger nucleases (Urnov et al., 2010) and TALE nucleases (Miller et al., 2011). Both of these methods seem applicable to Hydra and it is expected that they will be tried sooner than later.

\section{Is it time to try Hydra genetics again?}

One glaring omission from the toolkit for exploiting the Hydra genome is classical genetics. Sugiyama and Fujisawa attempted to develop Hydra as a genetic model in the 1970s (Sugiyama and Fujisawa, 1977). They began by carrying out sexual crosses between animals from ponds in the area of Mishima, Japan. This work led to two clear conclusions - doing classical genetics in Hydra is not easy, but very interesting developmental mutants can be identified (Sugiyama and Fujisawa, 1977; Sugiyama, 1983; Shimizu, 2012). Such mutants included ones that differed dramatically in size (Sugiyama, 1983), ones with impaired regeneration capacity (Sugiyama and Fujisawa, 1977), ones that failed to differentiate particular nematocyte lineages (Fujisawa and Sugiyama, 1978), and one with temperature-sensitive interstitial cells (Terada et al., 1988). These mutants have proved very valuable for developmental studies even though we have no idea what genes are mutated.

With the sequencing of a Hydragenome, it is worth revisiting the possibility of using genetic approaches to identify genes involved in developmental processes in Hydra. With next generation sequencing, it is now possible to map mutant genes by segregation analysis of sequence tags in bulked samples (Miller et al., 2007; Baird et al., 2008) or even by examining the genomes of the members a single human family afflicted with a genetic disease (Bamshad et al., 2011). Hydra should be amenable to either of these approaches. Adding chemical mutagenesis to the mix would allow use of the AEP strain of Hydra, which produces embryos readily in the lab and is used to make transgenic lines. The genome of the AEP strain has been sequenced and assembled (R. Steele and supported by grant R24GM080537 from the National Institute of General Medical Sciences. I am grateful to Paulyn Cartwright for sharing herinsights regarding hydrozoan evolution.

\section{References}

ALEXOPOULOS, H., BOTTGER, A., FISCHER, S., LEVIN, A., WOLF, A., FUJISAWA, T., HAYAKAWA, S., GOJOBORI, T., DAVIES, J.A., DAVID, C.N. and BACON, J.P. (2004). Evolution of gap junctions: the missing link? Curr Biol 14: R879-880.

AMIMOTO, Y., KODAMA, R. and KOBAYAKAWA, Y. (2006). Foot formation in Hydra: a novel gene, anklet, is involved in basal disk formation. Mech Dev 123: 352-361.

BAIRD, N.A., ETTER, P.D., ATWOOD, T.S., CURREY, M.C., SHIVER, A.L., LEWIS, Z.A., SELKER, E.U., CRESKO, W.A. and JOHNSON, E.A. (2008). Rapid SNP discovery and genetic mapping using sequenced RAD markers. PLoS One 3: e3376.

BAMSHAD, M.J., NG, S.B., BIGHAM, A.W., TABOR, H.K., EMOND, M.J., NICKERSON, D.A. and SHENDURE, J. (2011). Exome sequencing as a tool for Mendelian disease gene discovery. Nature Rev Genet 12: 745-755.

BODE, H.R. (1983). Reducing populations of interstitial cells and nematoblasts with hydroxyurea. Hydra: Research Methods. H. M. Lenhoff. New York, Plenum Press: 291-294.

BODE, H.R. (1996). The interstitial cell lineage of hydra: a stem cell system that arose early in evolution. J Cell Sci 109: 1155-1164.

BODE, H.R. (2011). Axis formation in Hydra. Ann Rev Genet 45: 105-117. BODE, H.R. (2012). The head organizer in Hydra. Int J Dev Biol 56: 473-478.

BOSCH, T.C. (2007). Why polyps regenerate and we don't: towards a cellular and molecular framework for Hydra regeneration. Dev Biol 303: 421-433.

BOSCH, T.C. (2009). Hydra and the evolution of stem cells. Bioessays 31: 478-486.

BOSCH, T.C., UNGER, T.F., FISHER, D.A. and STEELE, R.E. (1989). Structure and expression of STK, a src-related gene in the simple metazoan Hydra attenuata. Mol Cell Biol 9: 4141-4151.

BOSCH, T.C.G. and DAVID, C.N. (1987). Stem cells of Hydra magnipapillata can differentiate into somatic cells and germ line cells. Dev Biol 121: 182-191.

BRIDGE, D.M., STOVER, N.A. and STEELE, R.E. (2000). Expression of a novel receptor tyrosine kinase gene and a paired-like homeobox gene provides evidence of differences in patterning at the oral and aboral ends of hydra. Dev Biol 220: 253-262. 
BROUN, M., GEE, L., REINHARDT, B. and BODE, H.R. (2005). Formation of the head organizer in hydra involves the canonical Wnt pathway. Development 132 2907-2916.

BROWNE, E. (1909). The production of new hydranths in hydra by the insertion of small grafts. J Exp Zool 7: 1-37.

CALDER, D.R. (1988). Shallow-Water Hydroids of Bermuda: The Athecatae. Toronto, Royal Ontario Museum.

CAMPBELL, R.D. and BODE, H.R. (1983). Terminology for morphology and cell types. Hydra: Research Methods. H. M. Lenhoff. New York, Plenum Press: 5-14.

CARDENAS, M.M. and SALGADO, L.M. (2003). STK, the src homologue, is responsible for the initial commitment to develop head structures in Hydra. Dev Biol 264: 495-505.

CHAN, S.J., OLIVA, A.A., JR., LAMENDOLA, J., GRENS, A., BODE, H. and STEINER, D.F. (1992). Conservation of the prohormone convertase gene family in metazoa: analysis of cDNAs encoding a PC3-like protein from hydra. Proc Natl Acad Sci USA 89: 6678-6682.

CHAPMAN, J.A., KIRKNESS, E.F., SIMAKOV, O., HAMPSON, S.E., MITROS, T., WEINMAIER, T., RATTEI, T., BALASUBRAMANIAN, P.G., BORMAN, J., BUSAM, D., et al. (2010). The dynamic genome of Hydra. Nature 464: 592-596.

CHERA, S., DE ROSA, R., MILJKOVIC-LICINA, M., DOBRETZ, K., GHILA, L., KALOULIS, K. and GALLIOT, B. (2006). Silencing of the hydra serine protease inhibitor Kazal1 gene mimics the human SPINK1 pancreatic phenotype. J Cell Sci 119: 846-857

CHERA, S., GHILA, L., DOBRETZ, K., WENGER, Y., BAUER, C., BUZGARIU, W., MARTINOU, J.C. and GALLIOT, B. (2009). Apoptotic cells provide an unexpected source of Wnt3 signaling to drive hydra head regeneration. Dev Cell 17: 279-289.

CHERA, S., GHILA, L., WENGER, Y. and GALLIOT, B. (2011). Injury-induced activation of the MAPK/CREB pathway triggers apoptosis-induced compensatory proliferation in hydra head regeneration. Dev Growth Differ 53: 186-201.

CHIORI, R., JAGER, M., DENKER, E., WINCKER, P., DA SILVA, C., LE GUYADER, H., MANUEL, M. and QUEINNEC, E. (2009). Are Hox genes ancestrally involved in axial patterning? Evidence from the hydrozoan Clytia hemisphaerica (Cnidaria). PLOS ONE 4: e4231.

CHOURROUT, D., DELSUC, F., CHOURROUT, P., EDVARDSEN, R.B., RENTZSCH, F., RENFER, E., JENSEN, M.F., ZHU, B., DE JONG, P., STEELE, R.E. and TECHNAU, U. (2006). Minimal ProtoHox cluster inferred from bilaterian and cnidarian Hox complements. Nature 442: 684-687.

COLLINS, A.G., SCHUCHERT, P., MARQUES, A.C., JANKOWSKI, T., MEDINA, M. and SCHIERWATER, B. (2006). Medusozoan phylogeny and character evolution clarified by new large and small subunit rDNA data and an assessment of the utility of phylogenetic mixture models. Syst Biol 55: 97-115.

DAVID, C.N. (2012). Interstitial stem cells in Hydra: multipotency and decision-making. Int J Dev Biol 56: 489-497.

DAVID, C.N. and MURPHY, S. (1977). Characterization of interstitial stem cells in hydra by cloning. Dev Biol 58: 372-383.

FISHER, D.A. and BODE, H.R. (1989). Nucleotide sequence of an actin-encoding gene from Hydra attenuata: structural characteristics and evolutionary implications. Gene 84: 55-64.

FRASER, S.E. and BODE, H.R. (1981). Epithelial cells of Hydra are dye-coupled. Nature 294: 356-358.

FRASER, S.E., GREEN, C.R., BODE, H.R. and GILULA, N.B. (1987). Selective disruption of gap junctional communication interferes with a patterning process in hydra. Science 237: 49-55.

FUJISAWA, T. (2008). Hydra peptide project 1993-2007. Dev Growth Differ 50 Suppl 1: S257-S268.

FUJISAWA, T. and HAYAKAWA, E. (2012). Peptide signaling in Hydra. Int $J$ Dev Biol 56: 543-550.

FUJISAWA, T. and SUGIYAMA, T. (1978). Genetic analysis of developmental mechanisms in Hydra. IV. Characterization of a nematocyst-deficient strain. $J$ Cell Sci 30: 175-185.

GRENS, A., GEE, L., FISHER, D.A. and BODE, H.R. (1996). CnNK-2, an NK-2 homeobox gene, has a role in patterning the basal end of the axis in hydra. Dev Biol 180: 473-488.

GRENS, A., MASON, E., MARSH, J.L. and BODE, H.R. (1995). Evolutionary conservation of a cell fate specification gene: the Hydra achaete-scute homolog has proneural activity in Drosophila. Development 121: 4027-4035.

GRENS, A., SHIMIZU, H., HOFFMEISTER, S.A., BODE, H.R. and FUJISAWA, T. (1999). The novel signal peptides, pedibin and Hym-346, lower positional value thereby enhancing foot formation in hydra. Development 126: 517-524.

HARTL, M., MITTERSTILLER, A.-M., VALOVKA, T., BREUKER, K., HOBMAYER, B. and BISTER, K. (2010). Stem cell-specific activiation of an ancestral myc protooncogene with conserved basic functions in the early metazoan Hydra. Proc Natl Acad Sci USA 107: 4051-4056.

HASSEL, M. and BERKING, S. (1990). Lithium ions interfere with pattern control in Hydra vulgaris. Roux's Arch Dev Biol 198: 382-388.

HAYAKAWA, E., TAKAHASHI, T., NISHIMIYA-FUJISAWA, C. and FUJISAWA, T. (2007). A novel neuropeptide (FRamide) family identified by a peptidomic approach in Hydra magnipapillata. FEBS J 274: 5438-5448.

HEMMRICH, G., ANOKHIN, B., ZACHARIAS, H. and BOSCH, T.C. (2007). Molecular phylogenetics in Hydra, a classical model in evolutionary developmental biology. Mol Phylogenet Evol 44: 281-290.

HOBMAYER, B., JENEWEIN, M., EDER, D., GLASAUER, S., GUFLER, S., HARTL, M. and SALVENMOSER, W. (2012). Stemness in Hydra - a current perspective. Int J Dev Biol 56: 509-517.

HOBMAYER, B., RENTZSCH, F., KUHN, K., HAPPEL, C.M., VON LAUE, C.C. SNYDER, P., ROTHBACHER, U. and HOLSTEIN, T.W. (2000). WNT signalling molecules act in axis formation in the diploblastic metazoan Hydra. Nature 407: 186-189.

HOLSTEIN, T.W., HOBMAYER, E. and TECHNAU, U. (2003). Cnidarians: an evolutionarily conserved model system for regeneration? Dev Dyn 226: 257-267.

HOLSTEIN, T.W., MALA, C., KURZ, E., BAUER, K., GREBER, M. and DAVID, C.N. (1992). The primitive metazoan Hydra expresses antistasin, a serine protease inhibitor of vertebrate blood coagulation: cDNA cloning, cellular localisation and developmental regulation. FEBS Lett 309: 288-292.

HOULISTON, E., MOMOSE, T. and MANUEL, M. (2010). Clytia hemisphaerica: jellyfish cousin joins the laboratory. Trends Genet 26: 159-167.

HWANG, J.S., TAKAKU, Y., MOMOSE, T., ADAMCZYK, P., OZBEK, S., IKEO, K. KHALTURIN, K., HEMMRICH, G., BOSCH, T.C.G., HOLSTEIN, T.W., DAVID, C.N. and GOJOBORI, T. (2010). Nematogalectin, a nematocyst protein with GlyXY and galectin domains, demonstrates nematoctye-specific alternative splicing in Hydra. Proc Natl Acad Sci USA 107: 18539-18544.

JAGER, M., QUEINNEC, E., LE GUYADER, H. and MANUEL, M. (2011). Multiple Sox genes are expressed in stem cells or in differentiating neuro-sensory cells in the hydrozoan Clytia hemisphaerica. EvoDevo 2: 12

JIANG, Z., ROKHSAR, D.S. and HARLAND, R.M. (2009). Old can be new again HAPPY whole genome sequencing, mapping and assembly. Int J Biol Sci5:298-303.

KAWAIDA, H., SHIMIZU, H., FUJISAWA, T., TACHIDA, H. and KOBAYAKAWA, Y. (2010). Molecular phylogenetic study in genus Hydra. Gene 468: 30-40.

KHALTURIN, K., ANTON-ERXLEBEN, F., MILDE, S., PLOTZ, C., WITTLIEB, J., HEMMRICH, G. and BOSCH, T.C. (2007). Transgenic stem cells in Hydra reveal an early evolutionary origin for key elements controlling self-renewal and differentiation. Dev Biol 309: 32-44.

KHALTURIN, K., ANTON-ERXLEBEN, F., SASSMANN, S., WITTLIEB, J., HEMMRICH G. and BOSCH, T.C. (2008). A novel gene family controls species-specific morphological traits in hydra. PLoS Biol 6: e278.

KHALTURIN, K., HEMMRICH, G., FRAUNE, S., AUGUSTIN, R. and BOSCH, T.C. (2009). More than just orphans: are taxonomically-restricted genes important in evolution? Trends Genet 25: 404-413.

KURZ, E.M., HOLSTEIN, T.W., PETRI, B.M., ENGEL, J. and DAVID, C.N. (1991) Mini-collagens in hydra nematocytes. J Cell Biol 115: 1159-1169.

LENGFELD, T., WATANABE, H., SIMAKOV, O., LINDGENS, D., GEE, L., LAW, L., SCHMIDT, H.A., OZBEK, S., BODE, H. and HOLSTEIN, T.W. (2009). Multiple Wnts are involved in Hydra organizer formation and regeneration. Dev Biol330: 186-199.

LENHOFF, H.M., Ed. (1983). Hydra: Research Methods. New York, Plenum Press.

LOHMANN, J.U. and BOSCH, T.C. (2000). The novel peptide HEADY specifies apical fate in a simple radially symmetric metazoan. Genes Dev 14: 2771-2777.

LOHMANN, J.U., ENDL, I. and BOSCH, T.C. (1999). Silencing of developmental genes in Hydra. Dev Biol 214: 211-214

MARQUES, A.C. and COLLINS, A.G. (2004). Cladistic analysis of Medusozoa and cnidarian evolution. Invert Biol 123: 23-42. 
MARTÍNEZ, D.E., IÑIGUEZ, A.R., PERCELL, K.M., WILLNER, J.B., SIGNOROVITCH, J. and CAMPBELL, R.D. (2010). Phylogeny and biogeography of Hydra (Cnidaria: Hydridae) using mitochondrial and nuclear DNA sequences. Mol Phylogenet Evol 57: 403-410.

MILJKOVIC-LICINA, M., CHERA, S., GHILA, L. and GALLIOT, B. (2007). Head regeneration in wild-type hydra requires de novo neurogenesis. Development 134: 1191-1201.

MILLANE, R.C., KANSKA, J., DUFFY, D.J., SEOIGHE, C., CUNNINGHAM, S., PLICKERT, G. and FRANK, U. (2011). Induced stem cell neoplasia in a cnidarian by ectopic expression of a POU domain transcription factor. Development 138: 2429-2439.

MILLER, J.C., TAN, S., QIAO, G., BARLOW, K.A., WANG, J., XIA, D.F., MENG, X., PASCHON, D.E., LEUNG, E., HINKLEY, S.J., DULAY, G.P., HUA, K.L., ANKOUDINOVA, I., COST, G.J., URNOV, F.D., ZHANG, H.S., HOLMES, M.C., ZHANG, L., GREGORY, P.D. and REBAR, E.J. (2011). A TALE nuclease architecture for efficient genome editing. Nature Biotech 29: 143-148.

MILLER, M.R., DUNHAM, J.P., AMORES, A., CRESKO, W.A. and JOHNSON, E.A. (2007). Rapid and cost-effective polymorphism identification and genotyping using restriction site associated DNA (RAD) markers. Genome Res 17: 240-248.

MOKADY, O., DICK, M.H., LACKSCHEWITZ, D., SCHIERWATER, B. and BUSS, L.W. (1998). Over one-half billion years of head conservation? Expression of an ems class gene in Hydractinia symbiolongicarpus (Cnidaria: Hydrozoa). Proc Natl Acad Sci USA 95: 3673-3678.

MÜLLER, W.A. (1989). Diacylglycerol-induced multihead formation in Hydra. Development 105: 306-316.

NAITO, M., ISHIGURO, H., FUJISAWA, T. and KUROSAWA, Y. (1993). Presence of eight distinct homeobox-containing genes in cnidarians. FEBS Lett 333: 271-274.

NAKAMURA, Y., TSIAIRIS, C.D., OZBEK, S. and HOLSTEIN, T.W. (2011). Autoregulatory and repressive inputs localize Hydra Wnt3 to the head organizer. Proc Natl Acad Sci USA 108: 9137-9142.

NISHIMAYA-FUJISAWA, C. (2012). Germline stem cells and sex determination in Hydra. Int J Dev Biol 56: 499-508.

PAULI, A., RINN, J.L. and SCHIER, A.F. (2011). Non-coding RNAs as regulators of embryogenesis. Nature Rev Genet 12: 136-149.

PLICKERT, G., FRANK, U. and MÜLLER, W. (2012). Hydractinia, a pioneering model for stem cell biology and reprogramming somatic cells to pluripotency. Int J Dev Biol 56: 519-534.

PUTNAM, N.H., SRIVASTAVA, M., HELLSTEN, U., DIRKS, B., CHAPMAN, J., SALAMOV, A., TERRY, A., SHAPIRO, H., LINDQUIST, E., KAPITONOV, V.V., et al. (2007). Sea anemone genome reveals ancestral eumetazoan gene repertoire and genomic organization. Science 317: 86-94.

QUIQUAND, M., YANZE, N., SCHMICH, J., SCHMID, V., GALLIOT, B. and PIRAINO, S. (2009). More constraint on ParaHox than Hox gene families in early metazoan evolution. Dev Biol 328: 173-187.

RITZ, A., BASHIR, A. and RAPHAEL, B.J. (2010). Structural variation analysis with strobe reads. Bioinformatics 26: 1291-1298.

SCHALLER, H.C. (1973). Isolation and characterization of a low-molecular-weight substance activating head and bud formation in hydra. $J$ Embryol Exp Morphol 29: 27-38.

SCHALLER, H.C. (1975). A neurohormone from hydra is also present in the rat brain. J Neurochem 25: 187-188.

SCHALLER, H.C. and BODENMÜLLER, H. (1981). Isolation and amino acid sequence of a morphogenetic peptide from hydra. Proc Natl Acad Sci USA 78: 7000-7004.

SCHLAEPFER, D.D., FISHER, D.A., BRANDT, M.E., BODE, H.R., JONES, J.M. and HAIGLER, H.T. (1992). Identification of a novel annexin in Hydra vulgaris. Characterization, cDNA cloning, and protein kinase $\mathrm{C}$ phosphorylation of annexin XII. J Biol Chem 267: 9529-9539.

SCHUMMER, M., SCHEURLEN, I., SCHALLER, C. and GALLIOT, B. (1992). HOM HOX homeobox genes are present in hydra (Chlorohydra viridissima) and are differentially expressed during regeneration. EMBO J 11: 1815-1823.

SHENK, M.A., BODE, H.R. and STEELE, R.E. (1993). Expression of Cnox-2, a $\mathrm{HOM} / \mathrm{HOX}$ homeobox gene in hydra, is correlated with axial pattern formation. Development 117: 657-667.

SHIMIZU, H. (2012). Transplantation analysis of developmental mechanisms in Hydra. Int J Dev Biol 56: 463-472.
SHINZATO, C., SHOGUCHI, E., KAWASHIMA, T., HAMADA, M., HISATA, K., TANAKA, M., FUJIE, M., FUJIWARA, M., KOYANAGI, R., IKUTA, T., FUJIYAMA, A., MILLER, D.J. and SATOH, N. (2011). Using the Acropora digitifera genome to understand coral responses to environmental change. Nature 476: 320-323.

SMITH, K.M., GEE, L. and BODE, H.R. (2000). HyAlx, an aristaless-related gene, is involved in tentacle formation in hydra. Development 127: 4743-4752.

SOZA-RIED, J., HOTZ-WAGENBLATT, A., GLATTING, K.H., DEL VAL, C., FELLENBERG, K., BODE, H.R., FRANK, U., HOHEISEL, J.D. and FROHME, M. (2010). The transcriptome of the colonial marine hydroid Hydractinia echinata. FEBS J 277: 197-209

STEELE, R.E. (2006). Trembley's polyps go transgenic. Proc Natl Acad Sci USA 103: $6415-6416$

STEELE, R.E., DAVID, C.N. and TECHNAU, U. (2011). A genomic view of 500 million years of cnidarian evolution. Trends Genet 27: 7-13.

STEELE, R.E., LIEU, P., MAI, N.H., SHENK, M.A. and SARRAS, M.P., JR. (1996). Response to insulin and the expression pattern of a gene encoding an insulin receptor homologue suggest a role for an insulin-like molecule in regulating growth and development in hydra. Dev Genes Evol 206: 247-259.

SUGIYAMA, T. (1983). Isolating Hydra mutants by sexual inbreeding. Hydra: Research Methods. H. M. Lenhoff. New York, Plenum Press: 211-221.

SUGIYAMA, T. and FUJISAWA, T. (1977). Genetic analysis of developmental mechanisms in hydra. I. Sexual reproduction of Hydra magnipapillata and isolaltion of mutants. Dev Growth Differ 19: 187-200.

SUGIYAMA, T. and FUJISAWA, T. (1977). Genetic analysis of developmental mechanisms in hydra. III. Characterization of a regeneration-deficient strain. J Embryol Exp Morphol 42: 65-77.

TAKAHASHI, K. and YAMANAKA, S. (2006). Induction of pluripotent stem cells from mouse embryonic and adult fibroblast cultures by defined factors. Cell126:663-676.

TAKAHASHI, T. and FUJISAWA, T. (2009). Important roles for epithelial cell peptides in hydra development. Bioessays 31: 610-619.

TAKAHASHI, T., HATTA, M., YUM, S., GEE, L., OHTANI, M., FUJISAWA, T. and BODE, H.R. (2005). Hym-301, a novel peptide, regulates the number of tentacles formed in hydra. Development 132: 2225-2234.

TAKAHASHI, T., KOIZUMI, O., ARIURA, Y., ROMANOVITCH, A., BOSCH, T.C., KOBAYAKAWA, Y., MOHRI, S., BODE, H.R., YUM, S., HATTA, M. and FUJISAWA, T. (2000). Anovel neuropeptide, Hym-355, positively regulates neuron differentiation in Hydra. Development 127: 997-1005.

TAKAHASHI, T., KOIZUMI, O., HAYAKAWA, E., MINOBE, S., SUETSUGU, R., KOBAYAKAWA, Y., BOSCH, T.C., DAVID, C.N. and FUJISAWA, T. (2009). Further characterization of the $\mathrm{PW}$ peptide family that inhibits neuron differentiation in Hydra. Dev Genes Evol 219: 119-129.

TAKAHASHI, T., MUNEOKA, Y., LOHMANN, J., LOPEZDE HARO, M.S., SOLLEDER, G., BOSCH, T.C., DAVID, C.N., BODE, H.R., KOIZUMI, O., SHIMIZU, H., HATTA M., FUJISAWA, T. and SUGIYAMA, T. (1997). Systematic isolation of peptide signal molecules regulating development in hydra: LWamide and PW families. Proc Natl Acad Sci USA 94: 1241-1246.

TERADA, H., SUGIYAMA, T. and SHIGENAKA, Y. (1988). Genetic analysis of developmental mechanisms in hydra. XVIII. Mechanism for elimination of the interstitia cell lineage in the mutant strain Sf-1. Dev Biol 126: 263-269.

THOMSEN, S., TILL, A., WITTLIEB, J., BEETZ, C., KHALTURIN, K. and BOSCH, T.C. (2004). Control of foot differentiation in Hydra: in vitro evidence that the NK-2 homeobox factor $\mathrm{CnNK}-2$ autoregulates its own expression and uses pedibin as target gene. Mech Dev 121: 195-204.

TREMBLEY, A. (1744). Mémoires, pour servir à l'historie d'un genre de polypes d'eau douce, à bras en forme de cornes. Leiden, Jean and Herman Verbeek.

URNOV, F.D., REBAR, E.J., HOLMES, M.C., ZHANG, H.S. and GREGORY, P.D. (2010). Genome editing with engineered zinc finger nucleases. Nature Rev Genet 11: 636-646.

WITTLIEB, J., KHALTURIN, K., LOHMANN, J.U.,ANTON-ERXLEBEN, F. and BOSCH, T.C.G. (2006). Transgenic Hydra allow in vivo tracking of individual stem cells during morphogenesis. Proc Natl Acad Sci USA 103: 6208-6211.

WOOD, R.L. and KUDA, A.M. (1980). Formation of junctions in regenerating hydra: gap junctions. J Ultrastruct Res 73: 350-360.

ZACHARIAS, H., ANOKHIN, B., KHALTURIN, K. and BOSCH, T.C.G. (2004). Genome sizes and chromosomes in the basal metazoan Hydra. Zoology 107: 219-227. 


\section{Further Related Reading, published previously in the Int. J. Dev. Biol.}

Wnt signaling in hydroid development: ectopic heads and giant buds induced by GSK- 3beta inhibitors Werner Müller, Uri Frank, Regina Teo, Ofer Mokady, Christina Guette and Günter Plickert Int. J. Dev. Biol. (2007) 51: 211-220

BMP2/4 and BMP5-8 in jellyfish development and transdifferentiation Susanne Reber-Müller, Ruth Streitwolf-Engel, Nathalie Yanze, Volker Schmid, Michael Stierwald, Michael Erb and Katja Seipel Int. J. Dev. Biol. (2006) 50: 377-384

Posterior expression of nanos orthologs during embryonic and larval development of the anthozoan Nematostella vectensis Raquel Torras and Sergio González-Crespo Int. J. Dev. Biol. (2005) 49: 895-899

Patterning a multi-headed mutant in Hydractinia: enhancement of head formation and its phenotypic normalization. Werner A Müller, Regina Teo and Frank Möhrlen Int. J. Dev. Biol. (2004) 48: 9-15

Cubozoan jellyfish: an Evo/Devo model for eyes and other sensory systems Joram Piatigorsky and Zbynek Kozmik Int. J. Dev. Biol. (2004) 48: 719-729

The germ line and somatic stem cell gene Cniwi in the jellyfish Podocoryne carnea. Katja Seipel, Nathalie Yanze and Volker Schmid Int. J. Dev. Biol. (2004) 48: 1-7

The origins of axial patterning in the metazoa: how old is bilateral symmetry? John R Finnerty Int. J. Dev. Biol. (2003) 47: 523-529

The role of alpha-amidated neuropeptides in hydroid development--LWamides and metamorphosis in Hydractinia echinata.

Günter Plickert, Eva Schetter, Nicole Verhey-Van-Wijk, Jörg Schlossherr, Marlis Steinbüchel and Martin Gajewski

Int. J. Dev. Biol. (2003) 47: 439-450

Coral development: from classical embryology to molecular control.

Eldon E Ball, David C Hayward, John S Reece-Hoyes, Nikki R Hislop, Gabrielle Samuel, Robert Saint, Peter L Harrison and David J Miller

Int. J. Dev. Biol. (2002) 46: 671-678

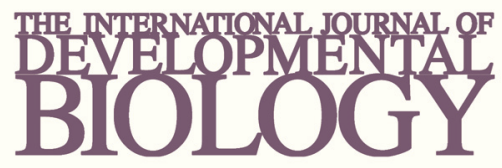

Volume 54 Nos. $6 / 7$
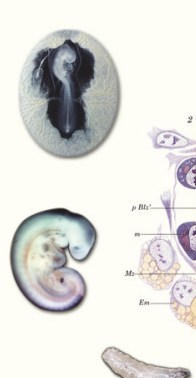

Developmental Hematopoiesis
Special Issue
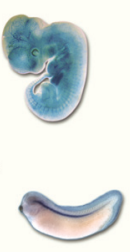

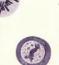

(6)

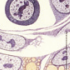

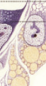

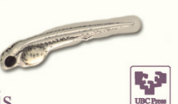

uncis
5 yr ISI Impact Factor $(2010)=2.961$

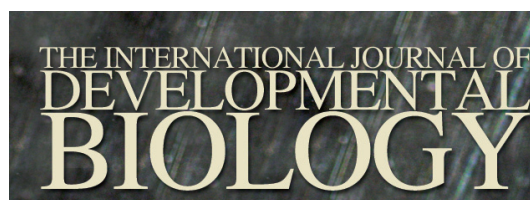

Volume 56 Nos.

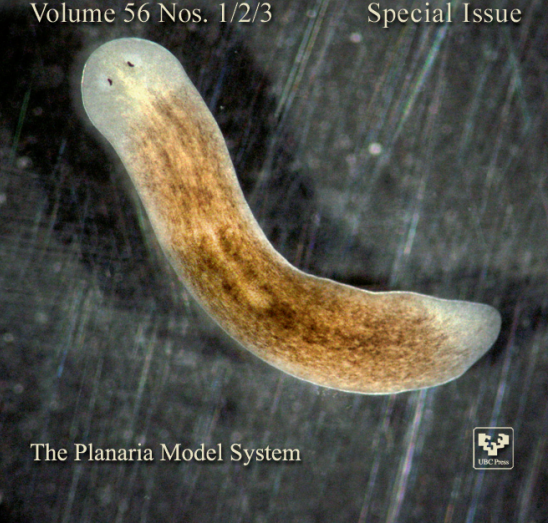

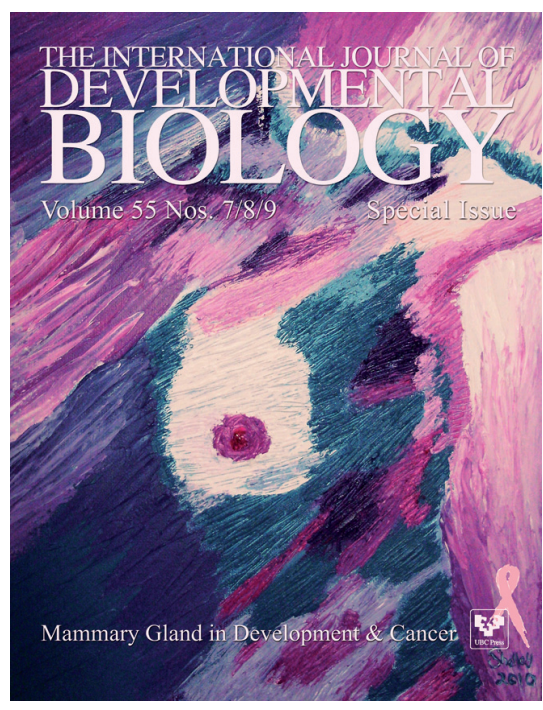

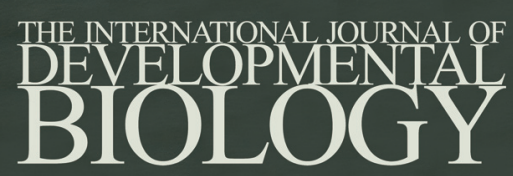

Volume 55 Nos. $4 / 5$

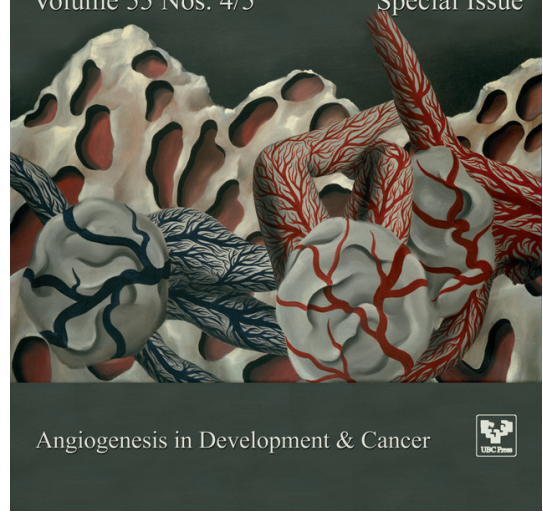

